\title{
Females with Gonadal Dysgenesis: Cytogenetic and
}

\section{Molecular Analysis}

Mona K. Mekkawy*, Samia A. Temtamy*, Suzan R. Ismail*, Ibtessam R. Hussein*, Nargues

M. Hassanein**

\begin{abstract}
Gonadal dysgenesis (GD) is a congenital defect in gonadal development related to abnormalities of genes controlling sexual differentiation and includes a wide spectrum of patients with variable phenotypes and chromosomal constitutions. This study aimed at studying the spectrum of chromosomal abnormalities as related to the phenotypic variability of GD cases and to detect the presence of $\mathrm{Y}$-chromosome specific sequences in these patients by using molecular techniques in order to allow early prophylactic management. Seventy females presenting with female GD were referred to the Human genetic clinic, National Research Center for cytogenetic analysis and genetic counseling. Patients were subjected to clinical examination, pedigree construction, cytogenetic and molecular analysis. Hormonal studies, pelvic ultrasonogrophy, Laparoscopy and gonadal biopsy were performed whenever possible. Patients were classified according to their Karyotypes into 9 groups. The most frequent Karyotype, was $45, X(34.3 \%)$. The association of $45, X$ with other cell lines were found at a rate of $28.6 \%$. The age of studied cases ranged between 15 days to 31.07 years (mean $=14: 0.9$ years). The total parental consanguinity rate reached $44.3 \%$. Gonadal dysgenesis and short stature are the two cardinal signs in these patients. Skeletal features were detected among all studied groups with highest scores in patients having complete $\mathrm{X}$ monosomy $(44.6 \%)$. Neck webbing was a characteristic sign of patients with non-mosaic $45, X$ karyotype. Dysmorphic features were detected in all groups with the exception of groups with 46, XX and 46, XY Karyotypes. Hirsutism and other virilizing signs were not commonly detected among the studied cases. Gonadoblastoma was detected in only one case among the 5 cases examined by Laparoscopic biopsy. Unidentified sex chromosomes markers constituted $35 \%$ of all our $45, X$ mosaic patterns. Molecular analysis of the markers using PCR technique proved the presence of $Y$ specific sequences, SRY, in three cases. The over all rate of $Y$ chromosomal material detected among these patients either by cytogenetic or molecular methods was $14,3 \%$.
\end{abstract}

\section{INTRODUCTION}

The term gonadal dysgenesis (GD) is structures and streak gonads. It includes a frequently used to describe all subjects heterogeneous group with large phenotypic with female genitalia, normal Mullerian and cytogenetic spectrum. ${ }^{(1)}$ It has been

\footnotetext{
* Human Genetics, National Research Center, Cairo. Egypt

${ }^{* *}$ Human Genetics, Medical Research Institute, Alexandria. Egypt
} 
documented that Y-chromosome contains the sex determining gene (SRY) which is located on the short arm close to the pseudo-autosomal region.

However, many other genes located on the X-chromosome and autosomes have crucial role for normal sexual development.(2)

The cytogenetic spectrum of females with GD, may extend from apparently normal 46, XX chromosomal complement to $46, X Y$ females and includes Turner syndrome (TS) patients with complete or partial Xmonosomy.(1)

A variety of other cytogenetic abnormalities have been also found, such as $\mathrm{Xp}$ or $\mathrm{Xq}$ deletions, isochromy of the $\mathrm{X}$ long arm, ring $\mathrm{X}$, and mosaicism that may include a cell line with Y-chromosome disclosed by DNA analysis. Further, 3\% of cases may have an unidentified sex chromosomal marker in pure or mosaic form. (3)

Turner syndrome is the major type of
GD in females and is of extremely variable phenotype. The most consistent findings are gonadal dysgenesis, short stature, and lymph edema. ${ }^{(4)}$

The pathogenesis of TS is complex and most authors believe that growth retardation, ovarian failure, and other physical abnormalities are separate and have distinct genetic effects. It was suggested that genes that play a role in the somatic stigmata are likely to be in Xp, where as gonadal dysfunction is likely to be due to inadequate dosage of $\mathrm{X}$-linked genes and/or poor pairing of the sex chromosomes in meiotic prophase.(5)

It has been proposed that all TS female with $45, X$ Karyotypes carry a cell line containing two sex chromosomes at a low level of mosaicism that is undetectable by standard cytogenetic methods. ${ }^{(3)}$

Theoretically, this hidden mosaicism may have a Y-chromosome specific $\mathrm{Y}$ sequences which are highly associated (up to $30 \%$ ) with the risk of gonadoblastoma.(6) 
So, it is important to study the incidence of Y-mosaicism and cryptic chromosomal sequences and its relation to phenotype among GD females in order to establish early and proper management.

The aim of this study was to study the spectrum of chromosomal abnormalities as related to the phenotypic variability of $G D$ cases and to detect the presence of $\mathrm{Y}$ chromosome specific sequences in these patients by using molecular techniques in order to allow early prophylactic management.

\section{PATIENTS AND METHODS}

The study included 70 females presenting with female gonadal dysgenesis. The cases were referred to the Human genetic clinic, National Research Center for cytogenetic analysis and genetic counseling. All patients were subjected to clinical examination and pedigree analysis. Hormonal studies, pelvic ultrasonography, laparoscopy, and gonadal biopsy were performed when ever possible.

\section{Cytogenetic analysis}

Peripheral blood lymphocytes cultures were performed to all cases according to the standard techniques. ${ }^{(7)}$ Metaphase spreads were treated with trypsin to obtain standard GTG banding pattern and Karyotypes were analysed following the ISCN nomenclature (2005). ${ }^{(8)}$

Clinical findings were recorded as the patient's score:

Stigmata of T.S were recorded for each case, and the scores were calculated as percentage of the positive stigmata. The mean percentage of the score was calculated for each group.

Statistical analysis was done to compare between groups using analysis ( $F$ test), and to compare between each two group using T-test. ${ }^{(9)}$

\section{Molecular analysis}

Molecular analysis using PCR for SRY gene amplification was performed for cases with unidentified ring or sex chromosomal marker, cases with hirsutism 
or clitoromegaly and cases with nonmosaic 45 , X karyotype to exclude hidden Y mosaicism. DNA was extracted from 10$\mathrm{ml}$ peripheral blood in EDTA as anticoagulant using Salting out technique. ${ }^{(10)}$

\section{Polymerase Chain Reaction}

(PCR): amplification was done using specific primers for SRY gene sequence located on the distal part of the short arm of the $\mathrm{Y}$ chromosome. DNA binding domain of the SRY gene was amplified with the primers SRY-IF and SRY-2R (the primer sequence was provided by Dr. Marc Fellous (Pasteur Institute, Paris, France) and manufactured commercially from Research Genetics Company). The $\beta$ globin gene region (770 bp) was coamplified with $0.2 \mu \mathrm{M}$ of primers CD6 and CD7 to serve as internal control. PCR reaction volume was $50 \mu \mathrm{L}$ containing 200 $500 \mathrm{ng}$ DNA, $50 \mathrm{mmol} / \mathrm{L} \mathrm{KCl}, 1.5 \mathrm{mmol} / \mathrm{L}$ $\mathrm{MgCl}_{2}, 10 \mathrm{mmol} / \mathrm{L}$ TOris-HCl (Ph 8.4), 0.2 $\mathrm{mmol} / \mathrm{L}$ each of the four dNTPs, 2.5-3 units of Taq polymerase (Promega) and 2 $\mu \mathrm{mol} / \mathrm{L}$ of each primer. Amplification conditions were: denaturation at $95^{\circ} \mathrm{C}$ for $5 \mathrm{~min}, 30$ cycles of $(45 \mathrm{sec}$ denaturation at $95^{\circ} \mathrm{C}, 1 \mathrm{~min}$ annealing at $55^{\circ} \mathrm{C}$, and $1 \mathrm{~min}$. extension at $72^{\circ} \mathrm{C}$ ), and final extension at $72^{\circ} \mathrm{C}$ for $10 \mathrm{~min}$. detection of PCR amplification was done by gel electrophoresis of $10 \%$ of PCR product on $2 \%$ agarose gel and visualized by ultraviolet $(\mathrm{U}-\mathrm{V})$ transilluminator. ${ }^{(11)}$

\section{RESULTS}

A total number of 70 females with GD were studied, chromosomal analysis was carried out for all cases and they were classified according to their karyotypes into 9 groups as shown in Table (1). Groups 2 and 3 and groups 6 and 7 were summed together in result tables to facilitate statistical analysis of clinical variants.

Mosaic patterns associated with $45, \mathrm{X}$ cell line were detected among twenty out of all studied cases (28.6\%). The most frequent mosaic cell line was $46, X, i(X q)$ 
constituting $35 \%$ of all $45, \mathrm{X} /$ mosaics. 45 , secondary sexual characteristics were $\mathrm{X} / 46, \mathrm{X},+$ mar constituted $25 \%$, and 45 , among the most variable clinical features. $\mathrm{X} / 46$, XY karyotype was detected among A rough estimate for somatic changes of $20 \%$ of mosaic Turner patients Table (2). patients in each group was done by the

Figures (1) and (2) showed the somatic feature score. The highest mean karyotypes of the patients no. 26 and 45, respectively. The age of the studied cases ranged between 15 days to 31.07 years (mean $=14: 09$ years). The total parental consanguinity rate reached $44.3 \%$, and it was highly prevalent in group 9 (83.3\%) and it was the lowest in group 4 (12.5\%). percentage score was observed in group 1 (39.8 \pm 10.9$)$, while it was lowest in group 9 (10.8 \pm 7.2) Table (1)

Significant statistical difference in the mean score was found between all groups $(\mathrm{F}=3.4$ and $\mathrm{P}<0.0001)$. Significant difference was also found between group 1

The most common presenting feature was short stature (in groups 1, $(2+3)$, and 5) while primary amenorrhea or delayed puberty was the main complaint in groups 8 and 9. Neonatal edema was present in only two patients within group $1(45, \mathrm{X}$, Karyotype).

According to the somatic features, they were highly variable among the studied groups. They all had gonadal dysgenesis, while, short stature, webbed or short neck, cubitus valgus, delayed and each of group $(2+3)(\mathrm{t}=2.3$ and $\mathrm{P}<$ $0.05)$; group $4(\mathrm{t}=2.8$ and $\mathrm{P}<0.05)$, group $(6+7) \quad(\mathrm{t}=3.3, \quad \mathrm{P}<0.002) ;$ group $8(\mathrm{t}=3.5$, $\mathrm{P}<0.005)$, and group 9(t=5.5, $\mathrm{P}<0.0001)$.

The skeletal anomalies detected among the studied groups were analysed and statistical analysis was done to compare between these different groups. The prevalence of high arched palate was marked in groups $(71.4 \%$ of cases) followed by group $1(66.7 \%)$, while it was totally absent in group 8. No significant difference 
was observed between the 9 groups $(P=$ 0.39).

Short neck and brachydactyly were mostly observed among patients of groups 1 and $(2+3)$, while they were not prevalent in other groups.

Cubitus valgus was highly prevalent among all studied groups being highest in groups $(6+7)(80 \%)$ and lowest in group 8 $(33 \%)$. No significant difference was observed between the different studied groups $(P=0.28)$.

Neck webbing was found almost linked to group 1 (29.2\%), while group $(2+3), 4,8$, and 9 were totally free of neck webbing.

Low hair line was observed with comparable frequencies in groups $1,(2+3)$, 4, $(6+7)$, and 8 .

Signs of lymphedema was exclusively reported among patients of group 1 (7 out of 24).

Facial dysmorphism was observed in $41.4 \%$ of the patients with highest frequency in group $1(62.5 \%)$ and lowest in group $(6+7)(30 \%)$. The most frequent type was sphinx shaped face. Dysmorphic features were totally absent in cases of groups 8 and 9. A significant difference in up slanting palpebral fissure was observed between groups $(P=0.03)$.

Widely spaced nipples were highly observed among patients of group 5 (85.7\%) and group 1 (79.2\%) followed by group $(2+3)(41.7 \%)$. This sign was totally absent in group (6+7) and a highly statistically significant difference between studied groups was recorded $(P=0.001)$.

Hirsutism was not a common finding in our patients. Only 9 out of the 70 cases studied had hirsutism (2.9\%).

All the patients in groups $1,(2+3)$, and $4(100 \%)$ had short stature, while it was present in $85.7 \%$ of patients in group 5 and $80 \%$ of group $(6+7)$. Only one case in both groups 8 and 9 showed short stature.

There was a statistically significant difference between studied groups 
regarding the statural height $(P=0.001)$.

Examination of external genitalia revealed that all the patients showed normal female external genitalia except cases no. 13, 15, and 19 (group 1) who had hypoplastic labia minora (with no history of circumcision); and case No. 68 (group 9) that showed clitoromegaly.

The prevalence of visceral anomalies was found very low among the studied patients. Cardiac abnormalities were detected among 4 cases, while renal anomalies were found in 5 cases only.

Evaluation of gonadrophic hormones and estrogen serum levels were performed for all cases and revealed high levels of $\mathrm{FSH} \pm \mathrm{LH}$ and low estradiol levels in all studied patients.

Pelvic ultra-sonography showed small ovaries with no follicular activity or streak gonads and small or hypoplastic uteri in all cases.

Laparoscopy and gonadal biopsy were performed when feasible for cases having 45, X/46, XY karyotypes and cases with $X Y G D$ to investigate the gonadal structure and the presence of gonadoblastoma. A total of six patients were examined: uses No. 39, 40, and 41 (from group 4 with 45, X/ 46, XY karyotypes). In case No. 39, the excisional biopsy showed streak ovaries with small gonadoblastoma on the right side. In both cases No. 40 and 41, gonadal biopsies revealed streak gonads with no testicular tissues. Laparoscopy showed fibrous streaks with small hypoplastic uteri and no testicular tissues in cases No. 63 and 64 (with 46, XY karyotype group 8). In case No. 66 (group 9) laparoscopy and gonadal biopsy revealed streak ovaries with normal uterus and tubes.

Molecular analysis using PCR technique:

PCR amplification for SRY gene sequences had been carried out for 36 cases: 16 cases from group 1 and 1 case with 45, X/47, XXX mosaicism were 
investigated to exclude the presence of hidden $Y$ mosaicism, 5 cases with unidentified sex chromosome markers and 1 patient with ring chromosome were studied for the evaluation of their origin, 8 patients with different karyotypes were investigated for the presence of $Y$ sequence as they showed virilization or atypical clinical findings. Other 5 patients having $\mathrm{Y}$ chromosome were also studied.

The 16 cases with $45, \mathrm{X}$ karyotype studied for hidden $Y$ mosaicism revealed negative signals.

Three cases with unidentified sex chromosome marker were found positive for SRY gene sequence (Cases No. 45, 46 and 51 from group 5). Cases having $Y$ chromosome by cytogenetic analysis were all proved to be positive for SRY sequence.

Case No. 43 with ring chromosome abnormality revealed negative SRY signal. These patients and the other case having ring chromosome (case No. 44, group 4) were subjected to FISH analysis using centromeric probes for $\mathrm{X}$ and $\mathrm{Y}$ chromosomes which proved the rings to be X-derived Table (3).

\section{DISCUSSION}

Gonadal dysgenesis is a congenital defect in gonadal development related to abnormalities of genes controlling sexual differentiation and includes a wide spectrum of patients with variable phenotypes and chromosomal constitutions. (2) Turner syndrome is the most common form, which results from complete or partial X-chromosomal monosomy and consists of highly variable and complex somatic changes. ${ }^{(12)}$

In the present study, the wide spectrum of patients was classified according to karyotypes in order to simplify analysis and to reflect the genetic heterogenicity in this complex disorder and its effect on the phenotype, Table (1).

Among the studied groups, 45, X was the most frequent karyotype constituting $34.3 \%$ of the total number of cases. It was 
previously recorded that $45, \mathrm{X}$ is the most frequent chromosomal constitution in TS and accounts for about $50 \%$ of Turner female. ${ }^{(13)}$

Other karyotypes related to TS also had relatively higher frequencies, which further confirms that TS is the most common form of GD in phenotypic females. ${ }^{(14,15)}$

The association of $45, X$ with other cell lines was found at a rate of $28.6 \%$ which is higher than previously recorded by Turnpenny and Ellard $(2005)^{(13)}$ and Nussbaum et al., (2001)(16) to be $20 \%-25 \%$, respectively.

The most common mosaic pattern detected in the present study was $45, \mathrm{X} / 46$, X, I (Xq), constituting $35 \%$ of all $45, X$ mosaics ( $10 \%$ of the total cases). This rate was found much higher than previously reported by Abul Hassan et al., (17) (1999) and Sybert and McCauley $(2004)^{(18)}$ being $13.6 \%$ and $8 \%$, respectively.

Non-mosaic iso-xq abnormality was detected in $7.1 \%$ of our patients. This coincides with the results obtained by Allanson and Graham (2002) ${ }^{(12)}$ and Sybert and McCauley $(2004)^{(18)}$ which was $5 \%$ and $10 \%$.

Cases having unidentified sex chromosomal marker comprised $10 \%$ of the total cases and $25 \%$ of $45, \mathrm{X} /$ mosais, a rate higher than that reported by Wolff $(2000)^{(19)}$ to be $20 \%$.

Mosaicism with 46, $X Y$ cell line occurred at a rate of $5.7 \%$ which is nearly similar to that obtained by Brant et al., (2006)(6) among Turner patients.

Structural X-chromosomal abnormalities had a more significant role in this study (14.3\%) than previously recorded (5\%10\%).(16,18) This probably because a wider range of GD females were included in this study.

Gonadal dysgenesis with $46, \quad X X$ Karyotype was present among $8.6 \%$ of our patients while $X Y$. GD had the lowest rate of all studied groups (4.3\%) which is 
compatible with the rarity of this disease. ${ }^{(6)}$

The age of presentation varied widely among different studied groups. It was the lowest in group of $45, X$ karyotype, as the patients of this group usually have the most severe phenotype with marked shortness of stature. The same finding was also detected by Abulhasan et al., (1999).(17) The oldest presentation age was noticed in cases with $X X, G D$ followed by $X Y, G D$ patients as they usually have normal stature with no somatic anomalies, thus they present later complaining of primary amenorrhea or delayed puberty. ${ }^{(1)}$

Parental consanguinity was highly prevalent among cases of the current study, being detected in $44.3 \%$ of them, with the highest rate in cases of group $9(83.3 \%)$. This is in accordance with the explanation that $X X, G D$ is an autosomal disorder which may have autosomal recessive inheritance or familial tendency. ${ }^{(1,20)}$

Gonadal dysgenesis and short stature are the two cardinal signs in our patients. GD was present in all patients of each group. Ovarian failure was associated with $\mathrm{Xp}$ and $\mathrm{Xq}$ deletions as well as other X-chromosomal aberrations, thus multiple genes must be involved in the pathogenesis of ovarian failure.(24) Break point analysis had led to define the locations Xp 11.2, 11.4, Xq13 - q22 and Xq26-q28 as important candidates for ovarian failure.

By phenotype/genotype correlations, short stature was found to be a cardinal feature of GD females being detected in $83 \%$ of them. All cases having complete or partial loss of one chromosome had manifested marked shortness in stature, even those with mosaic patterns. Short stature has been primarily explained by haplo-insufficiency of SHOX gene (located on Xp22-32).(22) In addition, break points analysis in cases with X-structural abnormalities had revealed that Xp 11.222. is a critical area harboring important statural genes in pathogenesis of short 
stature.(23)

Somatic features were highly variable among studied groups. Correlation of clinical and cytogenetic findings in the 70 females revealed different severities of somatics features as related to different karyotypic abnormalities.

Somatic features score was found closely related to the size of the part missing of $X$ chromosome. It was significantly highest in $45, X$ patients followed by patients with iso- $\mathrm{Xq}$ and sex chromosome marker, while it was significantly lower in cases with other variable $\mathrm{X}$ structural abnormalities and was the lowest in groups with $46, \mathrm{XX}$ and 46 , $X Y$ karyotypes. This clearly confirms the dosage effect of sex chromosomes on somatic development in those patients ${ }^{(26)}$ and are in accordance with the results obtained by Temtamy et al., (1992). ${ }^{(24)}$

Skeletal features were detected among all studied groups with highest scores in patients having complete $X$ monosomy and patients with iso-Xq abnormalities $\quad(44.6 \%$ and $41.7 \%$, respectively), while patients with normal 46, XX karyotypes had the lowest score (14.3\%). These patients with normal 46, XX karyotypes had the lowest score (14.3\%). These findings show close similarities with the results of Temtamy et al. (1992)(24) and zinn et al., (2001).(23)

The diversity of skeletal features was explained by SHOX haplo-insufficiency that results in various skeletal features when severely manifested, where as it leads to no features when subclinically manifested.(25)

Soft tissue stigmata were found of a significantly higher prevalence in cases with 45 , X karyotypes with a score of $30 \%$ as compared to other groups with scores ranging from $0 \%$ to a maximum of $14 \%$. Neck webbing was a characteristic sign of patients with non-mosaic $45, \mathrm{X}$ karyotype, being almost only detected among patients of that group with a rate of $29.2 \%$, while it was absent in all other studied groups (with 
the exception of only two cases).

This means that neck webbing is nearly linked to whole $\mathrm{X}$-monosomy $(45, \mathrm{X}$ karyotype). Similar observations were detected by Temtamy et al., (1992).(24) The present results are compatible with the explanation of soft tissue anomalies as deformational consequences resulting from haplo-insufficiency of lymphogenic gene.(23)

Dymorphic features were detected in all groups with the exception of groups with 46, XX and 46, XY karyotypes. The highest score was in patients with $45, \mathrm{X}$ and 45 , $X / 45, \quad X+\operatorname{mar}(62.5 \%$ and $57 \%$, respectively). The most frequent form of dysmorphism was sphinx shaped face. This would be explained by the effect of chromosomal imbalance ${ }^{(27)}$ and the compressive effect of distended lymphatics and lymphedema on the development skeletal tissues, as lymphedema is mostly related to $45, X$ karyotypes. ${ }^{(3)}$

Widely spaced nipples were also found at significantly higher rates in patients of groups 1 and $5(79.2 \%$ and $85.7 \%$, respectively). A very close rate was recorded by Temtamy et al., (1992)(24) this sign was found to be related to gene dosage effect and the degree of chromosomal imbalance rather than specific genes on $\mathrm{X}$ chromosome. ${ }^{(36)}$

Hirsutism and other virilizing signs were not commonly detected among cases of the present study and no correlation was found between those signs and the presence of $Y$ chromosome. It has been reported that hirsutism is not a common feature of TS. ${ }^{(5)}$

\section{Cardiac and renal anomalies were} infrequently detected among out patients. Cardiac anomalies have been detected on only $5.7 \%$ of all studied cases with the highest prevalence rate in the group with marker chromosome (33\%). Renal anomalies were present in $7.1 \%$ of patients with the highest rate among patients having iso- $\mathrm{Xq}$ abnormality (18.3\%). The prevalence of congenital cardiac anomalies 
among TS of females was previously estimated to be $23 \%-40 \%$ being highest in those with $45, \mathrm{X}$ monosomy. ${ }^{(27)}$ Congenital renal anomalies were reported to occur among $22 \%-24 \%$ with 45 , X karyotype. ${ }^{(24)}$ However, other studies reported low rates of those having mosaic X Monosomy. ${ }^{(3,5)}$

\section{Laparoscopic biopsies were} performed to five females having $Y$ chromosome in their genomic constitution. The results revealed the presence of gonadoblastoma in only one of them (20\%). No virilizing signs were noticed in that patient. The risk of developing gonodal tumours was reported to range from $14.3 \%-33.3 \%$, while other series had estimated a lower rate of gonodoblastoma.

Unidentified sex chromosomes markers constituted $35 \%$ of all our $45, \mathrm{X}$ mosaic pattern that is much higher than the rate recorded by wolff $(2000)^{(19)}$ who estimated sex chromosome markers to constitute about $20 \%$ of mosaic karyotypes. Molecular analysis of the markers using PCR technique proved the presence of $Y$ specific sequence, SRY in three cases out of five studied $(60 \%)$ figure (3). On the other hand, the rate of $45, \mathrm{X} /$ 46, $X Y$ mosaicism was similar to the previously reported $(5.7 \%$ of the total patients and $20 \%$ of $45, \mathrm{X}$ mosaicism).

The over all rate of $\mathrm{Y}$ chromosomal material detected among the patients of this study either by cytogenetic or molecular methods was $14,3 \%$. This rate is very near to the rate of $12.2 \%$ obtained by Gravholt et al., (2000)(28) among Turner females, all 45, $X$ patients molecularly tested for SRY gene sequence revealed negative results. Figure (4).

Early detection of $\mathrm{Y}$ chromosomal sequences is of great importance for proper counseling of patients at risk of gonadal tumour development.

Molecular analysis has the advantage of being rapid, and several samples can be analyzed in parallel. It could be applied to broader screening of large numbers of 
patients and greater sensitivity could be methods (karyotype and PCR or FISH achieved in recognizing mocaisim. techniques) than to test two tissues (blood, Moreover, it is easier and more practical to skin, gonadal tissue,...,etc.). test chromosomal mosaicism by two

Table (1): $\quad$ Frequencies of different Karyotypes among 70 females with gonadal dysgenesis and the mean score of clinical finding in different groups.

\begin{tabular}{|l|c|c|c|}
\hline \multicolumn{1}{|c|}{ Karyotype } & \multicolumn{2}{c|}{ Frequency } & \multicolumn{1}{c|}{$\begin{array}{c}\text { Mean \% } \\
\text { score } \pm \text { S.D }\end{array}$} \\
\hline & No. & $\%$ & \\
\hline Group 1: 45, X karyotype & 24 & 34.3 & $39.8 \pm 10.9$ \\
\hline Group 2: 46, X, i (xq) karyotype & 5 & 7.1 & $31.7 \pm 8.3$ \\
\hline Group 3: 45, X/46, X, i (Xq) karyotype & 7 & 10.0 & \\
\hline Group 4: 45, X/ other mosaics & 8 & 11.4 & $26.9 \pm 11.9$ \\
\hline Group 5 Karyotypes with marker chromosomes. (46, X, + mar) & 7 & 10.0 & $31.4 \pm 22.3$ \\
\hline Group 6: Other X structural abnormalities & 6 & 8.6 & $25.5 \pm 12.8$ \\
\hline Group 7: Mosaics 46, XX/ 46,X,X structural abnormalities & 4 & 5.7 & \\
\hline Group 8: 46, XY karyotype & 3 & 4.3 & $13.3 \pm 9.2$ \\
\hline Group 9: 46, XX karyotype & 6 & 8.6 & $10.8 \pm 7.2$ \\
\hline Total & $\mathbf{7 0}$ & $\mathbf{1 0 0}$ & $\mathbf{3 0 . 4} \pm \mathbf{1 5 . 5}$ \\
\hline
\end{tabular}

Table (2): Frequencies of mosaic patterns associated with 45,X karyotype.

\begin{tabular}{|l|c|c|c|c||}
\hline \multirow{2}{*}{ Mosaic pattern } & \multirow{2}{*}{ Group } & \multirow{2}{*}{$\begin{array}{c}\text { No. of mosaic } \\
\text { cases }\end{array}$} & & \multicolumn{2}{|c|}{ Frequency as related to: } \\
\cline { 4 - 5 } & & total no. of mosaic & total no. of cases \\
\hline $45, \mathrm{X} / 46, \mathrm{X}, \mathrm{I}(\mathrm{Xq})$ & 3 & 7 & $35 \%$ & $10 \%$ \\
\hline $45, \mathrm{X} / 46, \mathrm{XX}$ & 4 & 1 & $5 \%$ & $1.4 \%$ \\
\hline $45, \mathrm{X} / 47, \mathrm{XXX}$ & 4 & 1 & $5 \%$ & $1.4 \%$ \\
\hline $46, \mathrm{XY} / 45, \mathrm{X}$ & 4 & 4 & $20 \%$ & $5.7 \%$ \\
\hline $45, \mathrm{X} / 46, \mathrm{X}, \mathrm{r}(\mathrm{X})$ & 4 & 2 & $10 \%$ & $2.9 \%$ \\
\hline $45, \mathrm{X} / 46, \mathrm{X},+\mathrm{mar}$ & 5 & 5 & $25 \%$ & $8.6 \%$ \\
\hline Total & & 20 & $100 \%$ & $28.6 \%$ \\
\hline
\end{tabular}

NB: The overall frequency of marker chromosomes occurring in mosaic or non mosaic forms is $10 \%$. 
Table (3): $\quad$ Results of PCR amplification of SRY gene as compared to clinical signs of hyperandrogenism and cytogenetic findings.

\begin{tabular}{|c|c|c|c|c|c|c|}
\hline $\begin{array}{l}\text { No. of } \\
\text { cases }\end{array}$ & $\begin{array}{l}\text { Patient } \\
\text { No./Group }\end{array}$ & Age & Stature & $\begin{array}{l}\text { Clinical signs of } \\
\text { hyperandrogenism }\end{array}$ & Karyotype & SRY \\
\hline 1 & $38 / 4$ & 11:00 & Short & Absent & $\begin{array}{c}45, \mathrm{X}[86 \%] 47, \mathrm{XXX} \\
{[14 \%]}\end{array}$ & $-v e$ \\
\hline 2 & $40 / 4$ & $11: 04$ & Short & Absent & $\begin{array}{c}46, \mathrm{XY}[30 \%] / 45, \mathrm{X} \\
{[70 \%]}\end{array}$ & $+\mathrm{ve}$ \\
\hline 3 & $41 / 4$ & $15: 00$ & Short & Large hands and feet & $\begin{array}{c}46, \mathrm{XY}[32 \%] \\
/ 45, \mathrm{X}[68 \%]\end{array}$ & +ve \\
\hline 4 & $43 / 4$ & $15: 07$ & Short & Absent & $\begin{array}{c}45, X[76 \%] / 46, X, \\
r(X)[24 \%]\end{array}$ & -ve \\
\hline 5 & $42 / 4$ & 19:06 & Short & Hirsutism & $\begin{array}{l}46, X Y[38 \%] \\
/ 45, X[62 \%]\end{array}$ & $+v e$ \\
\hline 6 & $45 / 5$ & $31: 07$ & $\begin{array}{c}90^{\text {th }} \\
\text { percentile } \\
\text { (Eunuchoid) }\end{array}$ & Large hands and feet & $46, X,+\operatorname{mar}$ & $+\mathrm{ve}$ \\
\hline 7 & $46 / 5$ & 9.03 & Short & Hirsutism & $\begin{array}{c}45, X[63 \%] 46, X,+ \\
\operatorname{mar}[37 \%]\end{array}$ & $+\mathrm{ve}$ \\
\hline 8 & $47 / 5$ & 12:06 & Short & Absent & $\begin{array}{c}45, \mathrm{X}[90 \%] 46, \mathrm{X},+ \\
\operatorname{mar}[10 \%]\end{array}$ & -ve \\
\hline 9 & $50 / 5$ & $4: 03$ & Short & Absent & $\begin{array}{c}\text { 46,XX[3\%] 46,X, }+ \\
\operatorname{mar}[97 \%]\end{array}$ & $-v e$ \\
\hline 10 & $51 / 5$ & 12:06 & Short & Absent & $\begin{array}{c}45, \mathrm{X}[85 \%] 46, \mathrm{X},+ \\
\operatorname{mar}[15 \%]\end{array}$ & +ve \\
\hline 11 & $54 / 6$ & 10:02 & Short & Hirsutism & $\begin{array}{c}45, \mathrm{X}, \mathrm{t}(\mathrm{X} ; 9)(\mathrm{p} 11.4 \\
\mathrm{p} 22)[90 \%] 46, \mathrm{X},+ \\
\operatorname{mar}[10 \%]\end{array}$ & $-v e$ \\
\hline 12 & $57 / 6$ & 19:00 & $\begin{array}{l}\text { Tall }\left(>97^{\text {th }}\right. \\
\text { percentile) }\end{array}$ & $\begin{array}{l}\text { - Macrognathia } \\
\text { - Large hands }\end{array}$ & $46, X, \operatorname{inv}(X)(p ; q)$ & $-v e$ \\
\hline 13 & $62 / 8$ & 18:03 & Tall & Macrodontia & $46, X Y$ & $+\mathrm{ve}$ \\
\hline 14 & $63 / 8$ & $25: 00$ & Short & Absent & $46, X Y$ & $+v e$ \\
\hline 15 & $65 / 9$ & 15:03 & $\begin{array}{c}\text { Short } \\
\left(5^{\text {th }} \text { cent. }\right. \\
\text { Eunuchoid. })\end{array}$ & Absent & $46, X X$ & $-v e$ \\
\hline 16 & $66 / 9$ & 28:03 & $\begin{array}{c}\text { Mean } \\
\text { (Eunuchoid) }\end{array}$ & Absent & $46, X X$ & $-v e$ \\
\hline 17 & $67 / 9$ & 16:01 & $\begin{array}{c}\text { Mean } \\
\text { (Eunuchoid) }\end{array}$ & Absent & $46, X X$ & $-v e$ \\
\hline 18 & $68 / 9$ & $13: 00$ & Short & Clitoromegaly & $46, X X$ & -ve \\
\hline 19 & $69 / 9$ & 19:00 & $\begin{array}{l}\text { Tall, } \\
\text { eunuchoid }\end{array}$ & Absent & $46, X X$ & -ve \\
\hline 20 & $70 / 9$ & $14: 00$ & $\begin{array}{l}\text { Tall, } \\
\text { eunuchoid }\end{array}$ & Absent & $46, X X$ & $-v e$ \\
\hline
\end{tabular}




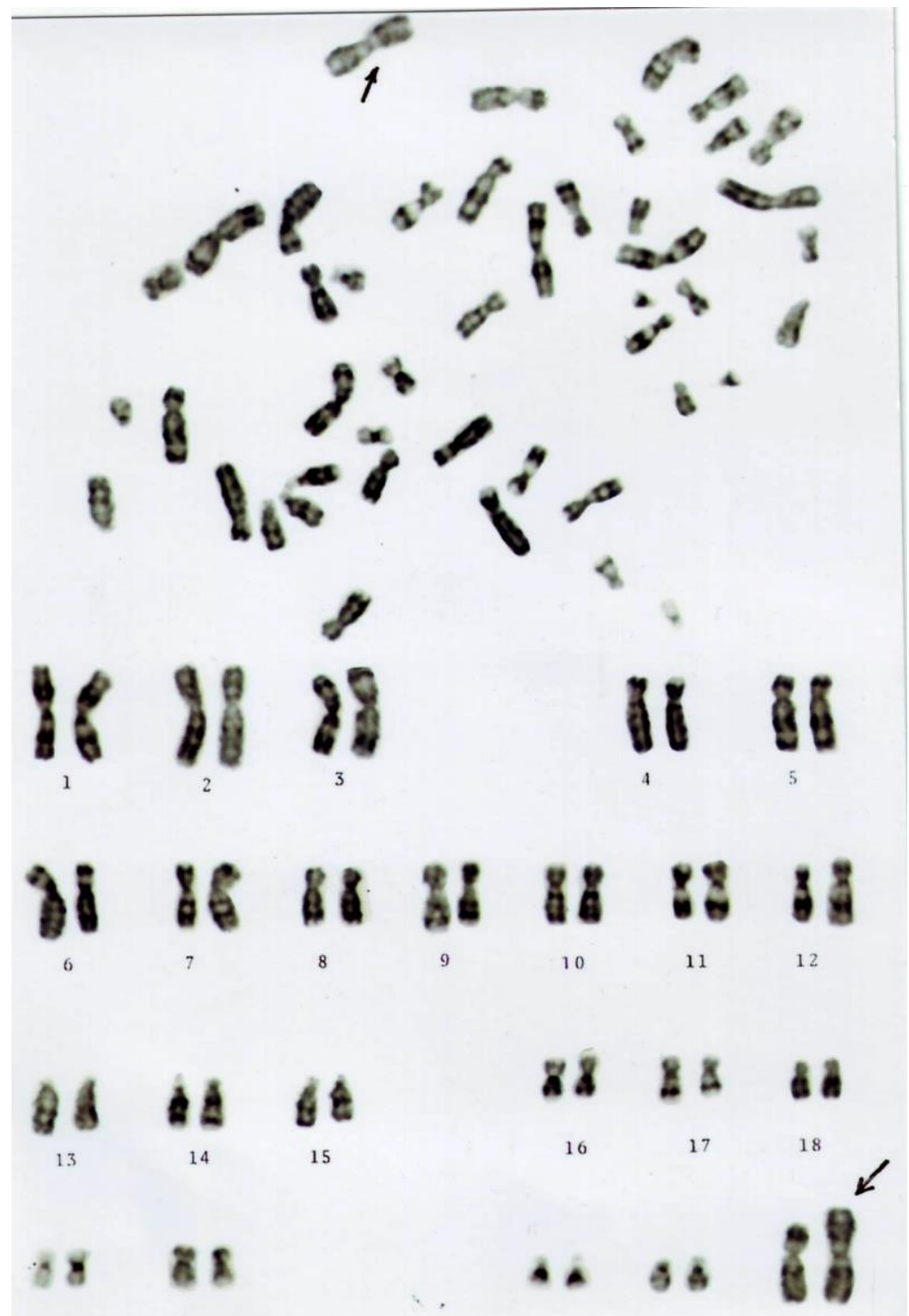

Fig. (1): G banded karyotype of patients No. 26 (group 2) showing 46,X,I (Xq). 

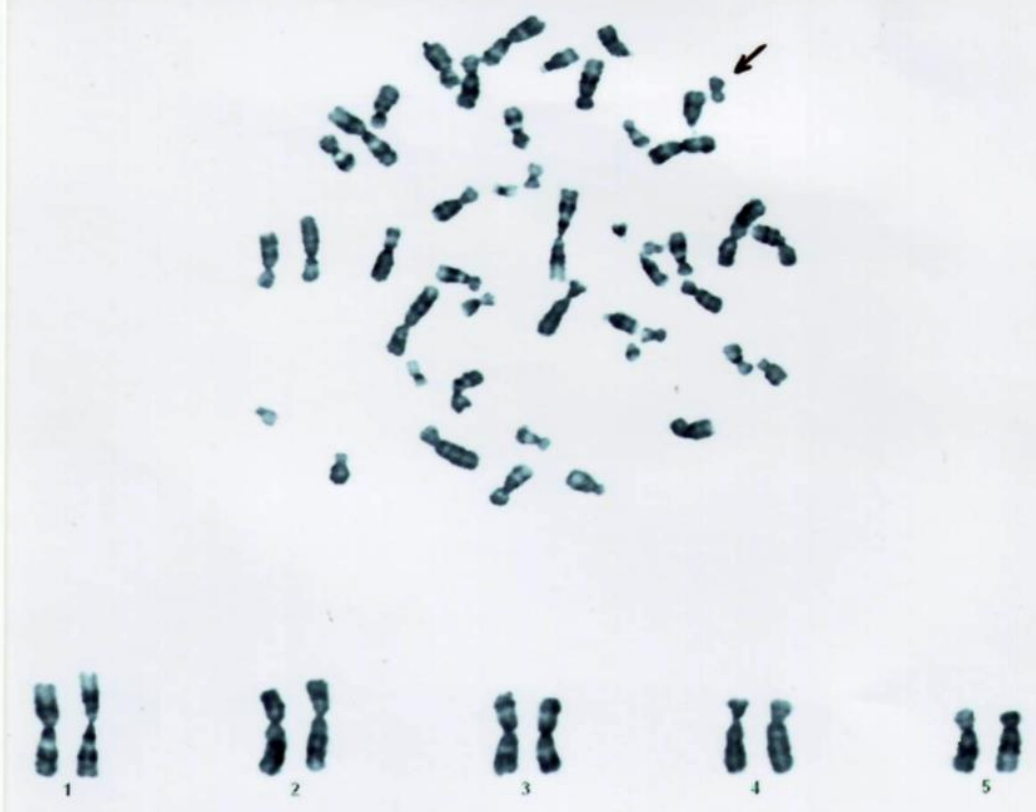

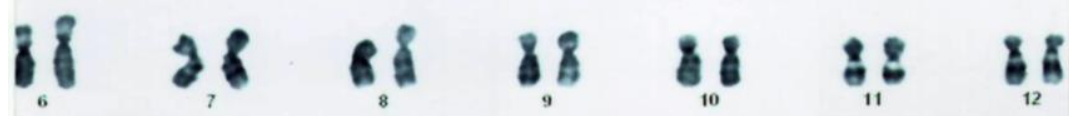

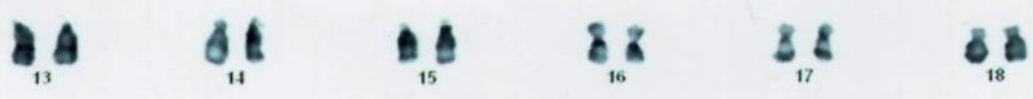

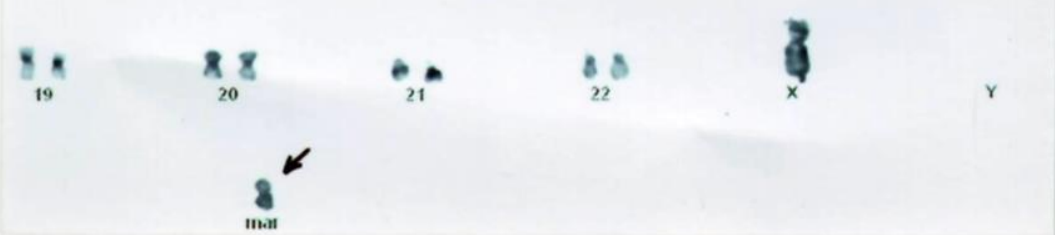

Fig. (2): G banded karyotype of patient No. 45 (group 5) showing 46,X,+ marker. 


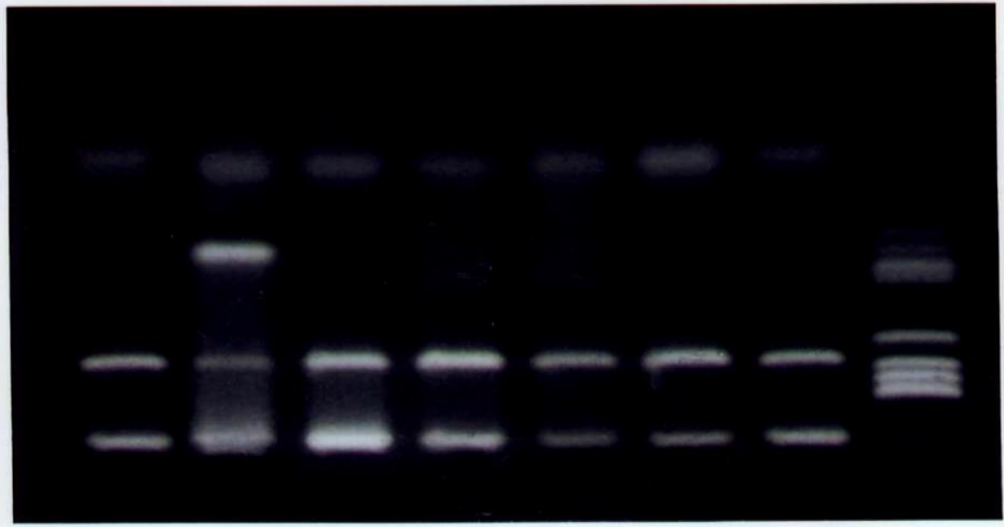

Fig. (3): Results of PCR amplification of SRY gene showing negative results (Lanes 2 to 6 , group 1).

Lane 1: shows phi X 174 Hae III marker.

Lane 7: positive control.

Lane 8: negative control.

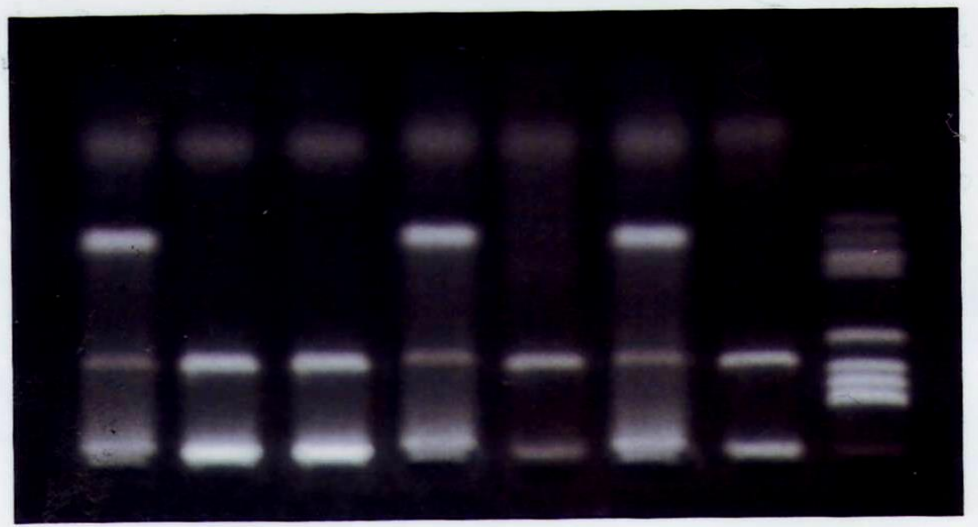

Fig. (4):Lane 1: Phi X 174 hae III marker.

Lane 2,4 and 6 show: negative amplification in cases No. 47,50 (group5) and 54 (group6).

Lane 3 and 5 show positive SRY amplification in cases No. 45 and 46 (group 5).

Lane 7: negative control.

Lane 8: positive control. 


\section{REFERENCE}

1. Simpson JL: Disorders of Gonads, Genital tact and genitalia, Vol.(2). In: Emery and Rimoin's principles and practice of medical Genetics. (2002): $4^{\text {th }}$ ed. Rimoin DL, Connor JM, Pyeritz RE, Korf BR (eds). New York, London, Churchill, Living stone.

2. Lukusa $\mathrm{T}$, Fryns $\mathrm{J}$ Pand van den Berghe $\mathrm{H}$ : The role of the $\mathrm{Y}$ chromosome in sex determination. Genet. Counseling. 1992;3:1-11.

3. Ogata T, Muroya K, Matsuo N: Turner syndrome and $\mathrm{Xp}$ deletions: Clinical and molecular studies in 47 patients. The Journal of clinical Endocrindogy and Metabolism. 2007; 86: 5498-5508.

4. Conway GS: The impact and management of Turner's syndrome in adult life. Best practice and Research clinical and molecular studies in 47 patients. The journal of clinical Endocrinology and Metabolism. 2002; 16: 243-61.

5. Cabrol S: Turner syndrome. Ann. Endocrinol (Paris). 2007; 68: 2-9.

6. Brant WO, Rajimwale $A$, Lovell $M$, Baldazzil. gonadoblastoma and Turner syndrome, J Urol. 2006;175(5):1858-60.

7. Verma ES, Babre A. Human chromosomes: Principles and Technique. $2^{\text {nd }}$. New York: Mc GrawHill; 1994.

8. ISCN. An international system for Human cytogenetic Nomenclature. 2005; Shaffer LG, Tommerup N(eds); S. Basel: Karger; 2005.

9. Ingelfinger J, Mostellar F, Thiodeau L, Ware J. Biostatistics in clinical Medicine. New York: Mc Graw Hill Inc; 1994. 20: 613-616.

10. Miller SA, Dykes DD, Puletsky HF. A simple salting out procedure for extracting DNA from human nucleated cells. Nucl. Acids Res. 1988; 16: 12-5.
11. Vollrath D, Foote S, Hilton A, Brown LG, Beer-Romero $\mathrm{P}$, Bogan JS, et al. The human $Y$ chromosome: a 43-interval map based on naturally occurring deletions. Science. 1992;258(5079):529.

12. Allanson JE, Grahma GE. sex chromosome abnormalities. In: Emery and Rimoin's principles and Practice of Medical Genetics. 4th edn. Rimoin DL, Conner JM, Pyeritz RE, Korf BR (eds). New York, London: Churchill Livingstone; 2002.

13. Turnpenny PD, Ellard S. Emery's Elements of Medical Genetics. 12th edn: Edinburgh, London, New York: Elsevier, Churchill, Livingstone; 2002.

14. Brewil V, Euller-Ziegler L. Gonadal dysgenesis and bone metabolism. Joint Bone Spine.2001; 68: 26-33.

15. Beck-Peccoz P, Persani L. Premature ovarian failure. Orphanet $\mathrm{J}$ Rare Dis. 2006;1:9.

16. Nussbaum RL, Mc Innes RR, Willard HF. Thompson and Thompson Genetics in Medicine. $6^{\text {th }}$ edn. Philadelphia, London, New York. W, B, Saunders company; 2001.

17. Abulhassan SA, Tayel SM, AL-Awadi SA. Mosaic Turner syndrome: cytogenetics versus FISH. Ann Hum Genetic. 1999; 63: 199-206.

18. Sybert VP, Mc Cauley E. Turner's Syndrome. N Engl J Med. 2004; 315: 1227-38.

19. Wolff DJ. Advances in laboratory evaluation of Turner Syndrome and its variants: beyond cytogenetics studies. Indian J Pediatr. 2000; 67: 825-9.

20. Kikuchi I, Takeuchi H, Kinoshita K. XY type gonadal dysgenesis, Trisomy $X$ and Variants. Nippon Rinsho. 2004; 62: 309-12.

21. Toniolo D. X-linked premature failure: a complex disease. Curropin Genet. Dev. 2006; 16: 293-300.

22. Rappold G, Blum WF, Shavrikova. 
Genotypes and phenotypes in children with short stature: clinical indicators of SHOX haplo- insufficiency. J Med Genet. 2007;44:306-13.

23. Zinn AR, Tonk VS, Chen Z. Evidence for a Turner syndrome Locus or Loci at Xp 11.2-P22.1, AM J Hum Genet. 1998; 63: $1757-66$.

24. Temtamy SA. Ghali I Salam MA, Hussein FH, Ezz Ehaa, Salah N. Karyotype/ Phenotype correlation in females with short stature. Clin Genet. 1992; 41: 147-51.

25. Kosho T, Muroya K, Nagai. skeletal
Metab. 1999;84:4613-21.

26. Epstein GJ. The consequences of chromosome imbalance: Principles, mechanisms and models. Cambridge: Cambridge University press; 1986.

27. Bione S, Toniolo D. X-chromosome genes and premature ovarian failure serum. Reprod. Med. 2000; 18: 51-8.

28. Gravholt $\mathrm{CH}$, Fedder J, Naerra RW, Muller. occurrence of gonadoblastoma in females with Turner syndrome and Y-chromosame material: a population study. J Clin Endocrinol Metab. 2000;85:3199-202. features and growth patterns in 14 patients with haplo-insufficiency of SHOX: implications for the development of Turner syndrome. J Clin Endocrinol 